\title{
Women Rights to Education and Its Implementation In Sindh
}

\author{
Naila Jabeen \\ Hamdard University Karachi-2013
}

\begin{abstract}
The study aims to analyze the factors influencing the women rights in Sind. The right to education is recognized as a human right by the United Nations. In this study we analyzed all those factors, bad policies, religious ground, social and cultural limitations, lack of interest, and lack of access to it and analyzed their effect on female education enrollment in Sukkur city.

The study was a quantitative research so strategy of research was survey and questionnaire. The target population for the study was large and diverse therefore stratified random sampling technique was used. The main tools for data collection were questionnaires and interview schedules. Document analysis was also used in the study. Data was analyzed statistically.

Our results suggest that the lack of good policies, income of the family, education of the parents and distance of school from home have a significant impact on the schooling decision for girls. The paper will contribute to the literature in such a manner that it investigates the factors that affect schooling decisions for girls.

Keywords: Women Rights, Income Level, Education, Socio-economic Status
\end{abstract}

\section{Background Of The Study}

\section{Introduction}

It has also been observed that female access to education in Pakistan is terribly slow. The current male to female literacy ratio is still at 65:40. According to the World Bank, there is no investment more effective for achieving development goals than educating girls. Everybody has the right to education, which has been recognized since the Universal Declaration of Human Rights (UDHR) in 1948. According to Article 28 of the United Nations Conventions on the Rights of the Child in 1989 November, the right of basic education is the basic right of the children and call for all nations to make primary education compulsory and available free to all. According to the UNESCO, $60 \%$ of the girls and $72 \%$ of boys were enrolled in primary school in the year 2008. Furthermore, $28 \%$ girls and $37 \%$ boys were enrolled in the secondary education for the same year.

It is, therefore, in this research study we will make an attempt to bring clarity in the concept of women rights to education in the perspective of international human rights standard which the government of Pakistan is under an obligation to ensure. We also investigate the predominant customary practice and their inference on women of the country.

\section{Statement Of The Problem}

Educational options are limited in Pakistan. While the demand for education rests high, poorer families will only send their children to a school system that is important to their everyday lives and economic needs. The Annual Status of (school) Education Report (ASER) released the report, according to it, one-third of the children of 6 to 16 years of age in Balochistan and Sindh are out of school. This ratio rises to 61.2 percent in Sindh and77.7 percent in Balochistan, in regard to early childhood education. Almost 75 percent of the students drop out of schools before reaching class-X, while millions leave in the first two years in the primary schools.

(The Nation, February 02, 2013)

The study thus investigates the factors that influence the access of secondary education in Sind. Two main questions guide this study: What are the reasons for children never attending school? And for those who did attend, what are the reasons for dropping out before completing the basic level? In answering these questions, the study will:

(i) examine trends in basic education enrollment with specific focus on gender gaps;

(ii) examine the varying performance of governorates in raising enrollment, especially among girls;

(iii) analyze the factors perceived as barriers to schooling of children.

\section{Research Questions}

Further these questions would be consider,

- What is the background of women's right to education? 
- Is there any significant difference between the academically qualified parents \&less qualified parents and their daughter's education?

- Is there any significant positive relationship between girls education and their parents income level?

- Is there any significant negative relationship between girl's education and their school distance from home?

- What are the customary Practices in respect of women's education? and;

- What is the way forward

\section{SCOPE OF THE STUDY}

This study was conducted in Taluka Sukkar in Sind. The end result of this study includes practicable recommendations, which in turn is helpful to the policy and decision makers, planners and other to improve girls' situation and development at large.

\section{RESEARCH DESIGN}

Questionnaire and interview protocol were designed. This research was conducted through selfadministered questionnaire distributed among 50 girls and interviewed 30 parents with varying age, monthly income, profession, language, residential area (socio-economic status) and education in Sukkur city. The study was performed in five union councils out of 12 Uc's of Sukkur city, Sindh's second largest city, derives its name from its headquarters town Sukkur

\section{POPULATION \& SAMPLING}

Population of the present study consist of the female respondents age group 11-16 either they were studying or not or dropped out. According to Annual Status of Education Report 2012, school enrollment ratio of children (age group 11-16) is 61.15\%, children who never enrolled are $24.35 \%$ while drop out ratio of this age group is $14.5 \%$. Stratified random sampling technique was adopted for the study.

\section{DATA COLLECTION}

Data was collected through personal visits. Data collection will consist of surveys and interviews. Both the primary and secondary data was collected

\section{DATA ANALYSIS}

Data was presented by using various methods such as tables, graphs, charts, percentages and words.

\section{DATA ANALYSIS AND FINDINGS}

This research was conducted through self-administered questionnaire. Section A of the instrument focused on the demographic information on the respondents, 50 girls age 11-16 and 30 mothers. The girls were classified as attending schools (58\%), never attending schools (10\%) and dropped out of schools (32\%). It was hoped to obtain some indications of the significance of various factors in respect of school enrolment, such as: transport problem, distance to school; family size, parental occupation; parental education, and the attitude of mothers, fathers and the children themselves to their education.

$\mathrm{T}$ he data used in this study come from survey and interviews. To reflect the most recent picture on girls' education we primarily use the District Sukkur SEMIS 2011. We used standard survey instruments to collect data on girls and mothers (age, relation to head, education, work status, total no of children ...etc.) and household living conditions (total no of household members, no of working members, level of income, area of living). We collected detailed information on children's education including, current schooling status, cost of education, current schooling status of their siblings, current work status, reasons for never attending school and reasons for dropping out of school (as perceived by the respondents-- the mothers). In addition collected information on category of school (government, private or welfare), distance of school from home, school environment, scholarship program.. The data is collected based on a stratified sample design.

TABLE 1 Enrollment by class in Government schools for the year 2011-12 of City Sukkur:

\begin{tabular}{|l|l|l|l|}
\hline School level & Total & Boys & Girls \\
\hline Primary & 61 & 5,962 & 6,840 \\
\hline Secondary & 20 & 5,270 & 4,186 \\
\hline Higher Secondary & 03 & 1,356 & 2,661 \\
\hline
\end{tabular}

The table 01 gives details of primary and middle school enrolment and the reasons why children do not go to school. The tables 01 indicate that there is a sharp drop in enrolment after the primary classes in girls (2654). It indicating that males and females both drop-out from school but girls rate high (2654) than boys (692) after primary education. Table 01 presents the school enrolment rates for boys and girls for different categories, and it 
can be immediately seen that the biggest disparity is for the higher secondary school enrolment for boys (3914) than girls (1525).

Above table indicates that there is slight difference in enrolment ratio from Primary class to secondary and higher secondary class. However we can observe significant difference in enrolment ratio from primary class to onward that up to $12 \mathrm{th}$. The ratio is 6,840 girls at primary level in city Sukkur but tremendously decreases to 4,186 for secondary level for girls and 2,661 for higher secondary level Table-1 is also a clear indicator for declined number of female students in the educational institutions of city Sukkur especially after primary classes but in case of boys the ratio is 5,962 boys at primary level and sustain to 5,270 for secondary level but tremendously decreases to 1,358 for higher secondary level. It's very clear from above table that number of boys students is becoming lesser after secondary class as compare to girls students. Even though girls enter primary school in the same proportions as boys, dropout rates are higher among girls than boys particularly in standard 1 and in the upper standards of primary school.

FIGURE 01 Government school's enrollment of Girls \& Boys for the year 2011-12 of City Sukkur

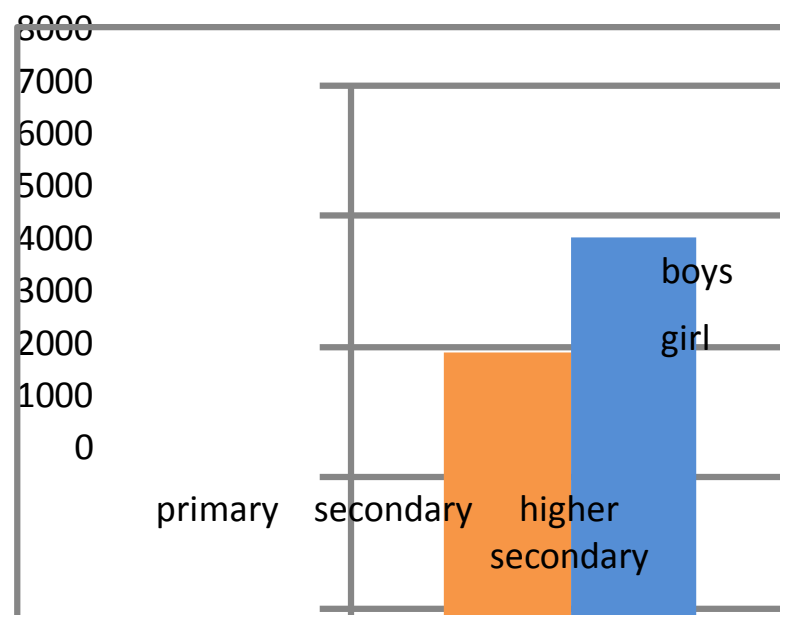

FIGURE 02 Enrollment in Mixed school Girls \& Boys for the year 2011-12 of City Sukkur

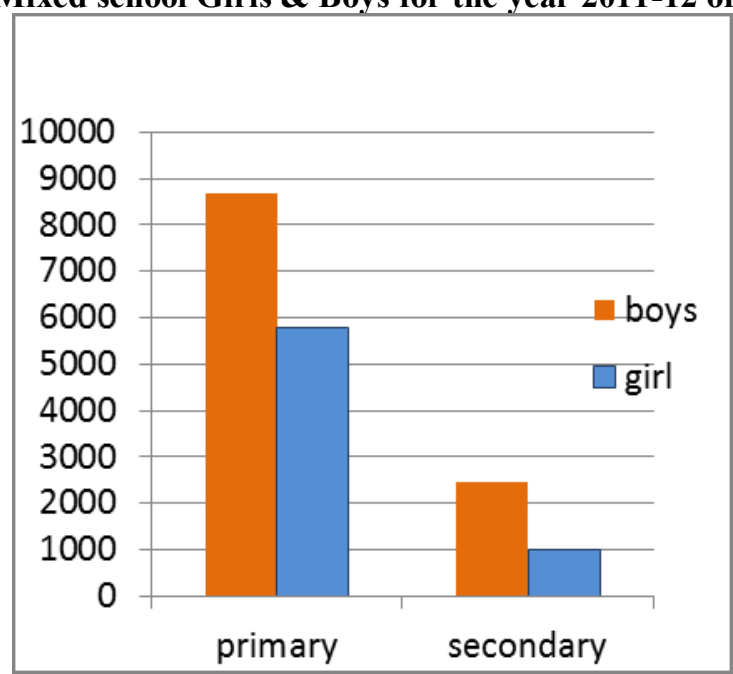

FIGURE 03 Government school's enrollment of Girls

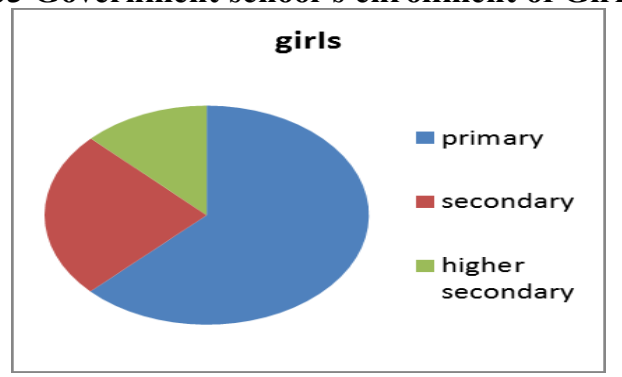

FIGURE 04 Government school's enrollment of Boys 


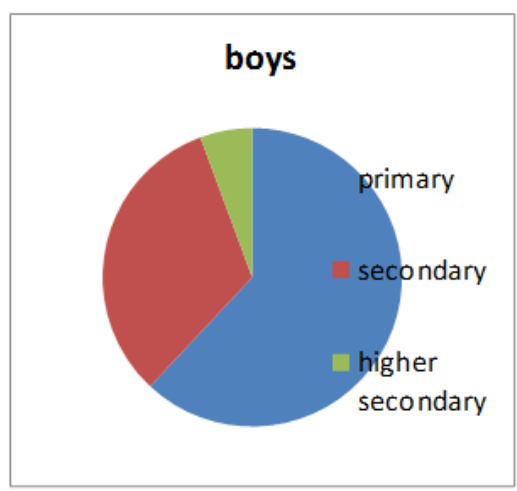

TABLE 02 Current Schooling Status of Respondents (Girls)

\begin{tabular}{|l|l|l|}
\hline Schooling status & Girls & Girls\% \\
\hline Never attend & 05 & $10.0 \%$ \\
\hline Currently attend & 29 & $58.0 \%$ \\
\hline Dropped out & 16 & $32.0 \%$ \\
\hline
\end{tabular}

TABLE 03 Respondents (Girls) Parents Income Level

\begin{tabular}{|l|l|l|}
\hline Income Level & NO of Respondents(Girls) & NO of Respondents(Girls) $\%$ \\
\hline Poor (Below 15,000) & 14 & $28 \%$ \\
\hline Average (15,000 to 25,000) & 11 & $22 \%$ \\
\hline Rich(above 25,000) & 17 & $34 \%$ \\
\hline Don't Know & 08 & $16 \%$ \\
\hline
\end{tabular}

TABLE 04 Current Schooling Status of Girls, by Income levels

\begin{tabular}{|l|l|l|l|}
\hline Schooling status & $\begin{array}{l}\text { Poor \% } \\
\text { (Below15,000) }\end{array}$ & $\begin{array}{l}\text { Middle \% } \\
(15,000 \text { to 25,000) }\end{array}$ & $\begin{array}{l}\text { Rich\% } \\
\text { (above 25,000) }\end{array}$ \\
\hline Never attend & 80.0 & 20.0 & --- \\
\hline Currently attend & 17.2 & 13.7 & 69.0 \\
\hline Dropped out & 66.6 & 22.2 & 11.1 \\
\hline
\end{tabular}

Table 04 shows the schooling status of girls by level of household income. Overall $80 \%$ out of school girls belong to poor families while $20 \%$ out of school girls belong to middle income families and none from rich group. Hence $66.6 \%$ of the age group is in school leaving belong to poor families While $22.2 \%$ girls dropped out belong to middle families and only $11.1 \%$ girls dropped out who belong rich families. . However, in terms of household wealth, the table also shows a positive association with school attendance and a negative association with non-attendance and dropout. That is, school attendance increases with household wealth while nonattendance and dropping out systematically decreases with household wealth. Table shows girls from poor household are the most likely to have never attended school (80\%) compared to girls from middle class (20\%) and richer households (none).

We have found a positive connection between household income and schooling of children (69\%). Income is seen as a crucial factor for schooling decisions since it determines the amount of available resources for each child and the family. Therefore, having a higher financial resource is positively associated with more education. The rise in the household income decreases the probability of no schooling and increases the probability of formal education for boys and girls.

\section{FIGURE 05 Current Schooling Status of Girls, by Income levels}

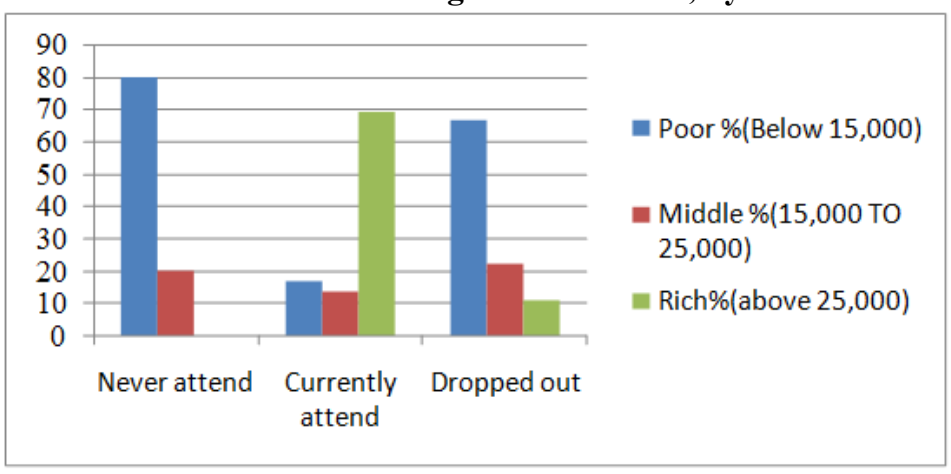

TABLE 05 Mean of the Monthly income of respondents (girls) Parents 


\section{Monthly Average Income}

$15,20,05,10,10,06,35,16,08,08,10,40,20,06,06,08,50,10,10,100,20,06,40,40,15,40,30,35,50,30,40,50,50$ $, 100,35,100,50,55,25,25,40,05,06,25,20,20,35,25,35,07$

The mean of the Monthly income of respondents are 29.64 which shows that on average they are in between 25000 to 30,000 , whereas median and mode explains that more people having monthly income in between 24,000 to 30,000 . This study assessed the effect of poverty and low income level on girl's access to education. In above table 2.2 here $80 \%$ girls were those who never attend school belong to poor families $20 \%$ belong to middle families and none from rich families. Mothers (70\%) belong to poor and middle families said, if there is not enough money to feed then how parents send their children in to school, then family background also counts a lot. if a child comes from poor family then it results in dropouts and absence. Dropped out respondents (girls)66.6\% belong to poor families while 05 girls dropped out of school in the 5 th grade, 08 in the 9 th grade, one in the $10^{\text {th }}$ grade, and 02 in the 11 th grade

TABLE 06 Average Family Size of Respondents (Girls)

\begin{tabular}{|l|l|l|}
\hline Family Size & NO of Respondents(Girls) & NO of Respondents(Girls) $\%$ \\
\hline Below to 05 & 08 & $16 \%$ \\
\hline Below to 08 & 19 & $38 \%$ \\
\hline Below to 10 & 20 & $40 \%$ \\
\hline Above to 10 & 03 & $06 \%$ \\
\hline
\end{tabular}

FIGURE 06 Average Family Size of Respondents (Girls)

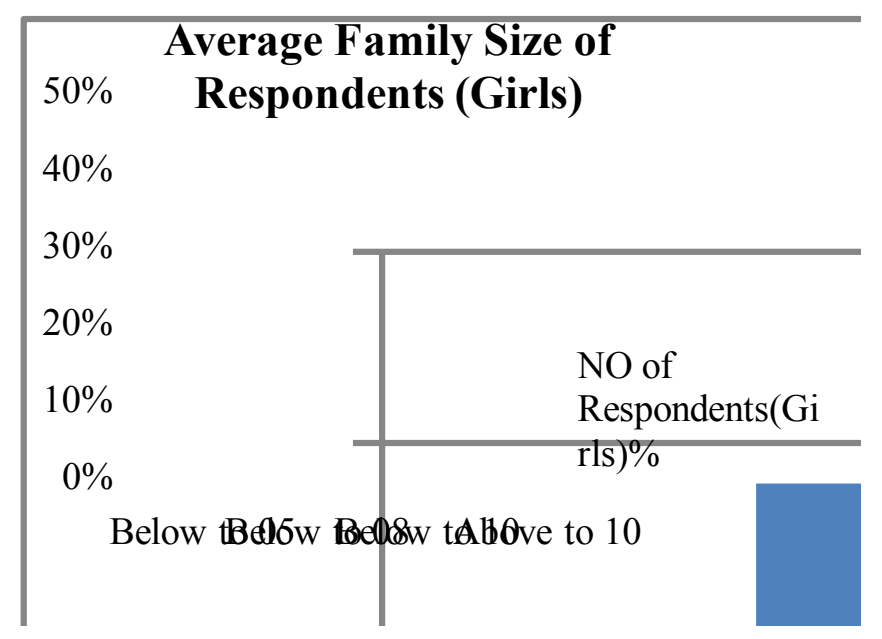

The family size amongst the children surveyed was as above below to 05 family members $16 \%$, below to 08 were $38 \%$, below to 10 were $40 \%$ and above to 10 were $06 \%$. That means average family size $(78 \%)$ of respondents were 07. According to District Sukkur SEMIS 2011 the average family size in Sukkur is 06.so most of the sample belongs to average family size. The family size and family composition both have significant for girls' sample. First measure is computed by taking the number of people living in the same household into consideration. This decreases the probability of attaining school for girls and boys. "We want to get education to our children girls or boys but we haven't enough financial resources”, said Noor Jahan Bibi (a mother belong poor family).According to table below $73.3 \%$ respondents average family size were 6.5 .

TABLE 07Average Family Size of Respondents (Parents)

\begin{tabular}{|l|l|l|}
\hline Family Size & NO of Respondents(Girls) & NO of Respondents(Girls) $\%$ \\
\hline Below to 03 & 03 & $10 \%$ \\
\hline Below to 05 & 08 & $16 \%$ \\
\hline Below to 08 & 19 & $38 \%$ \\
\hline Below to 10 & 20 & $40 \%$ \\
\hline Above to 10 & 03 & $06 \%$ \\
\hline
\end{tabular}


FIGURE 07 Average Family Size of Respondents (Parents)

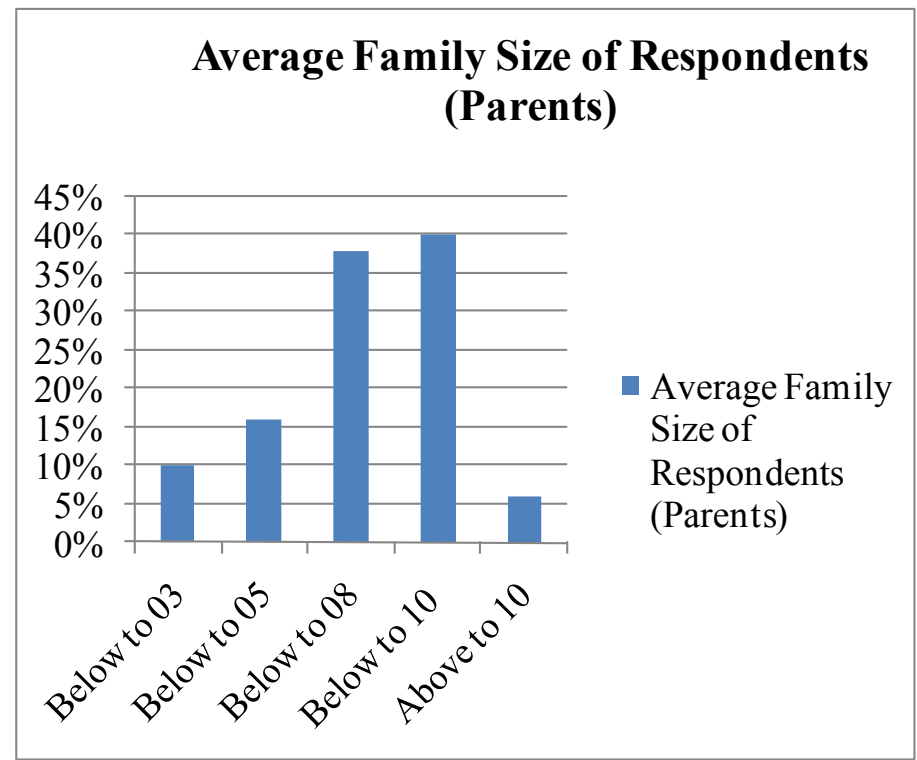

TABLE 08 Respondents Parents Professions

\begin{tabular}{|l|l|l|}
\hline Professions & NO of Respondents(Girls) & NO of Respondents(Girls) $\%$ \\
\hline Agriculture & --- & --- \\
\hline Business & 17 & $34 \%$ \\
\hline Skilled worker & 10 & $20 \%$ \\
\hline Jobs & 16 & $32 \%$ \\
\hline Others & 05 & $10 \%$ \\
\hline
\end{tabular}

FIGURE 08 Respondents Parents Professions

\section{Respondents Parents}

Professions

TABLE 09 Source of Income of Respondents (Parents)

\begin{tabular}{|l|l|l|l|l|l|}
\hline Levels & Agriculture & Job & Buissness & Skilled ker & Guardian \\
\hline No of Respondents & 1 & 16 & 6 & 5 & 2 \\
\hline $\begin{array}{l}\text { No of } \\
\text { Respondents } \%\end{array}$ & $3.3 \%$ & $53.3 \%$ & $20 \%$ & $16.6 \%$ & $6.6 \%$ \\
\hline
\end{tabular}

TABLE 10 Parents Education Level (\%) of Respondents (Girls)

\begin{tabular}{|l|l|l|l|l|l|l|l|l|l|}
\hline Gender & $\begin{array}{l}\text { Never } \\
\text { Attend }\end{array}$ & Madrasa & Primary & Middle & Matric & Inter & B.A & M.A \\
\hline Father & 14.0 & 12.0 & 14.0 & 2.0 & 26.0 & 6.0 & 12.0 & 4.0 \\
\hline Mother & 4.0 & 30.0 & 20.0 & 4.0 & 14.0 & --- & 10.0 & 12.0 & 8.0 \\
\hline
\end{tabular}


TABLE 11 Respondents (Mothers) Education Level(\%)

\begin{tabular}{|l|l|l|l|l|l|l|l|l|l|}
\hline Levels & $\begin{array}{l}\text { Never } \\
\text { Attend }\end{array}$ & Nazra & Alma & Primary & Middle & Matric & Inter & B.A & M.A \\
\hline $\begin{array}{l}\text { No of } \\
\text { Respondents\% }\end{array}$ & 16.6 & 26.6 & 3.3 & 23.3 & 6.6 & 6.6 & 6.6 & 6.6 & 3.3 \\
\hline
\end{tabular}

FIGURE 09Parents Education Level (\%) of Respondents (Girls)

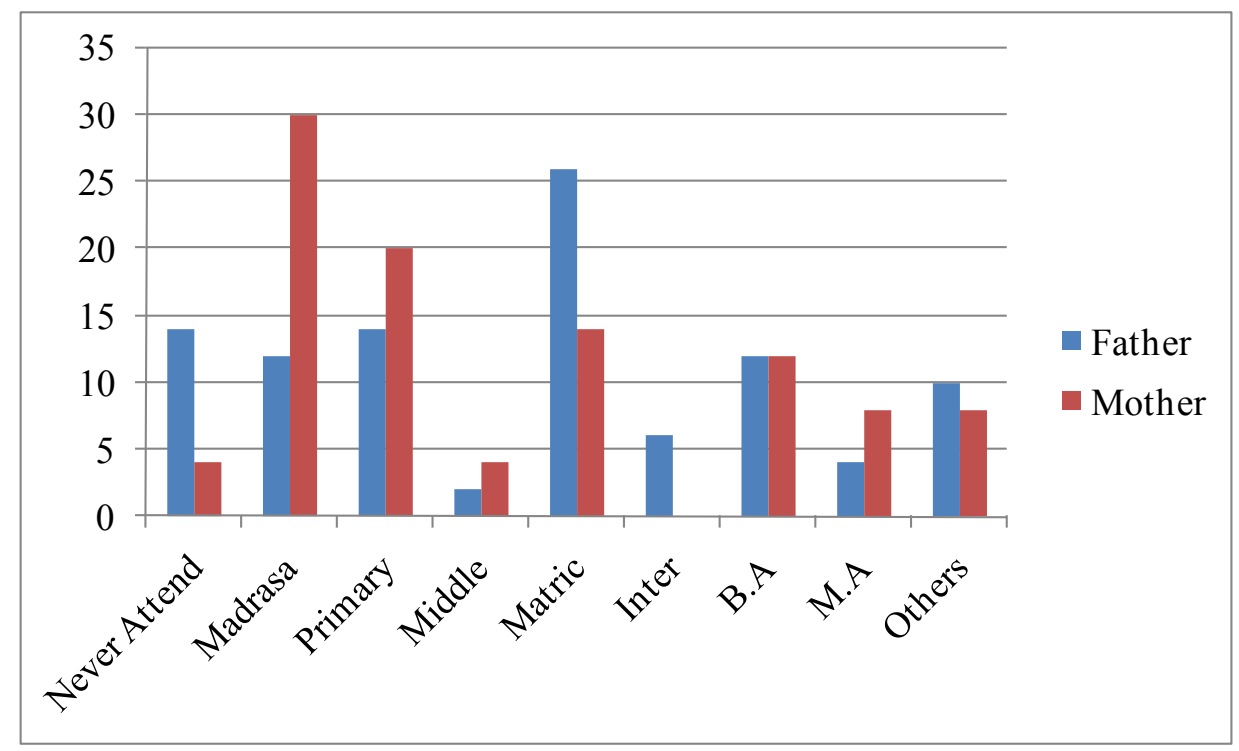

TABLE 12 Parents Education Level (\%) of those Respondents (Girls) who enrolled

\begin{tabular}{|l|l|l|l|l|l|l|l|l|l|}
\hline Gender & $\begin{array}{l}\text { Never } \\
\text { Attend }\end{array}$ & Madrasa & Primary & Middle & Matric & Inter & B.A & M.A & Others \\
\hline Father & 6.8 & 13.7 & 10.3 & 3.4 & 27.5 & 10.3 & 17.2 & 3.4 & 13.7 \\
\hline Mother & 3.4 & 27.5 & 24.1 & 6.8 & 24.1 & 3.4 & 10.3 & 17.2 & 6.8 \\
\hline
\end{tabular}

FIGURE 10 Parents Education Level (\%) of those Respondents (Girls) who enrolled

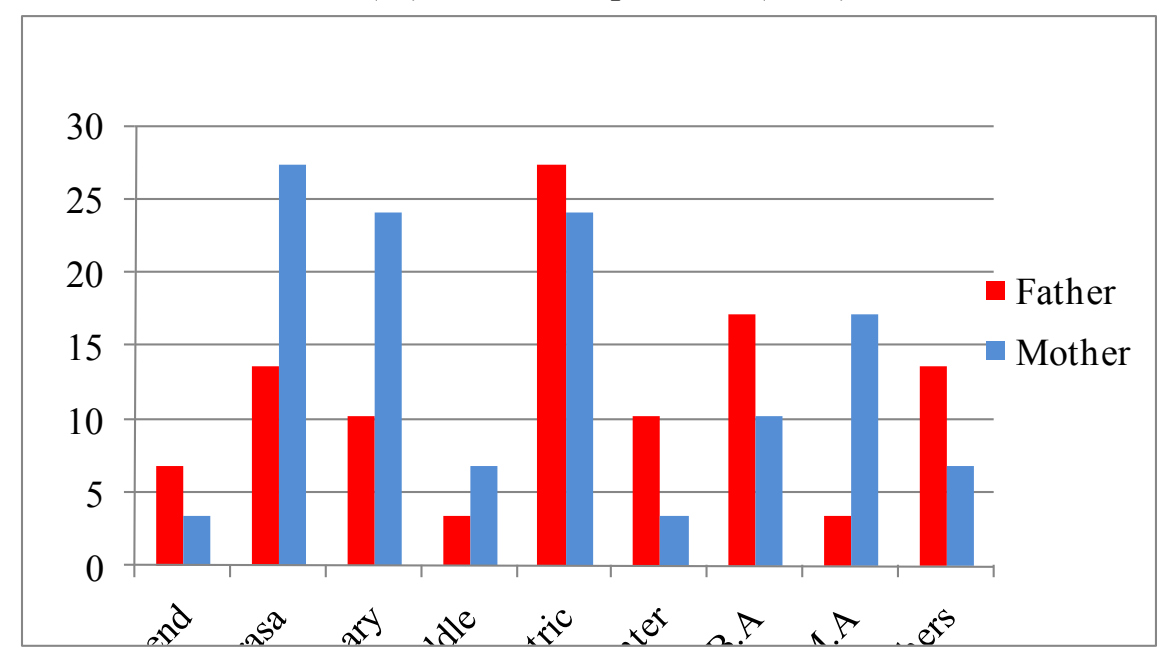

Another factor that will be influential for the children's schooling prospects is the parental education. In above chart here $6.8 \%$ respondent's father never attends school while 3.4\% mothers never attend school. Hence $85.8 \%$ respondent's fathers were those who attend school and $44.7 \%$ fathers were those who enrolled in higher secondary classes while $92.1 \%$ mothers were those who attend school and $37.7 \%$ mothers enrolled in higher secondary classes that means more educated parents are more willing to send their kids to schools. 
TABLE 13 Respondent (Girls) Enrollment ratios in government or Private schools

\begin{tabular}{|l|l|l|}
\hline Schools & No of Respondents & No of Respondents \% \\
\hline Government & 18 & $58 \%$ \\
\hline Private & 11 & $35 \%$ \\
\hline Madrasa & 02 & $6.6 \%$ \\
\hline
\end{tabular}

FIGURE 11 Respondent (Girls) Enrollment ratios in government or Private schools

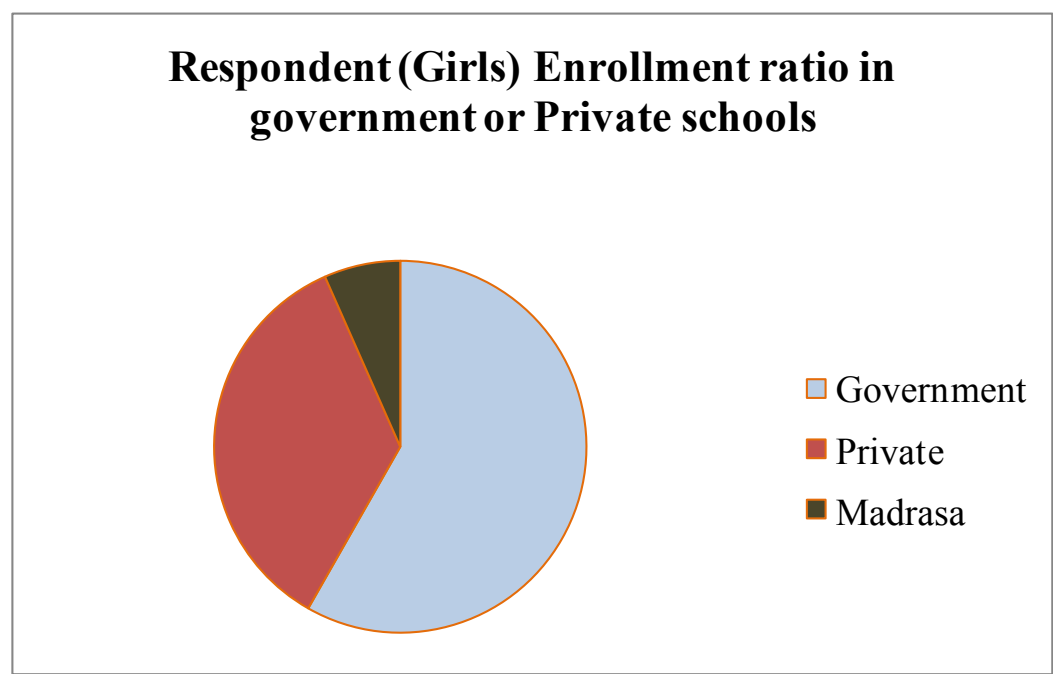

According to above table shows that the majority of basic education students are in public schools (62\%), with $6.6 \%$ in religious schools and $35 \%$ in private schools, which reflects a small contribution of the private sector in the education sector

TABLE 14 Distance of school

\begin{tabular}{|l|l|l|}
\hline Distance of school & NO of Responses & NO of Responses $\%$ \\
\hline Near & 10 & $35 \%$ \\
\hline Far & 19 & $65 \%$ \\
\hline
\end{tabular}

FIGURE 12 Distance of school

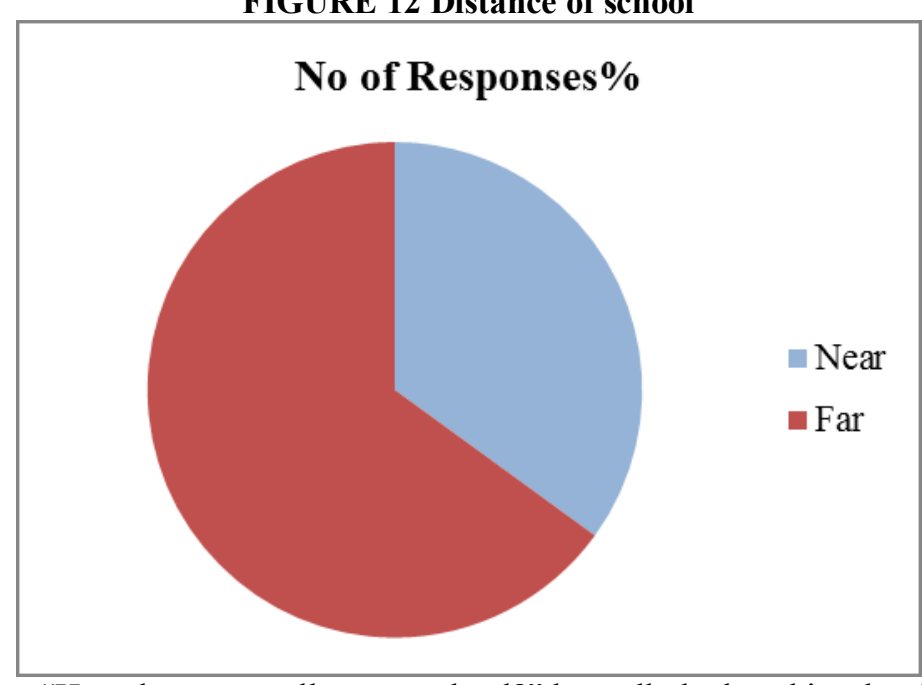

When asked respondents "How do you usually go to school?" by walk, by bus, bicycle, rickshaw, car, lorry or another way $37 \%$ replied by walk and $63 \%$ used any conveyance.

TABLE 15 Means of Transport

\begin{tabular}{|l|l|l|}
\hline Means of Transport & NO of Responses & NO of Responses\% \\
\hline By Walk & 11 & $37 \%$ \\
\hline By conveyance & 18 & $63 \%$ \\
\hline
\end{tabular}




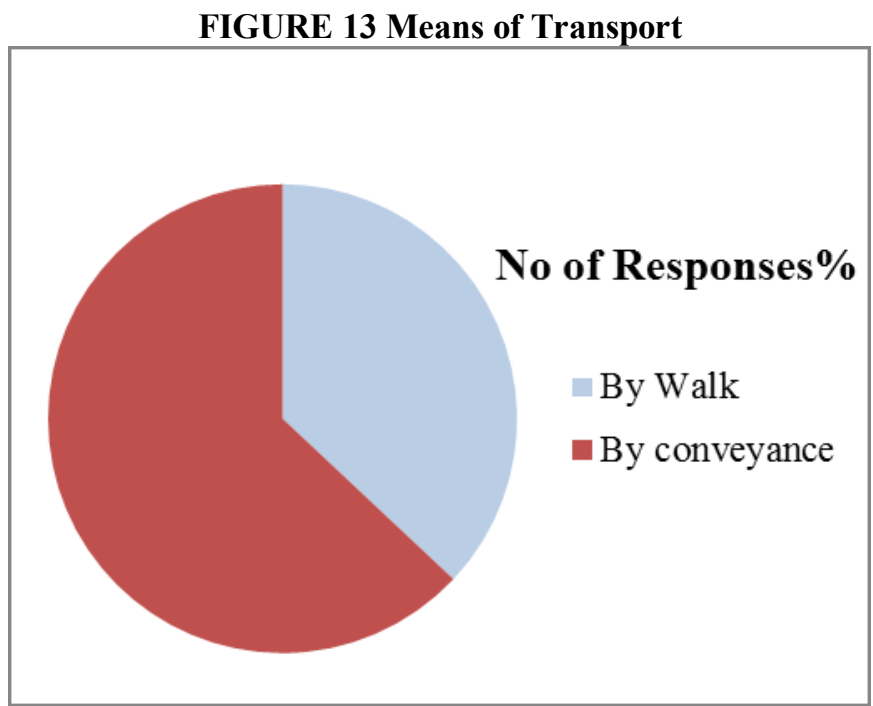

TABLE 16 Nature of Transport

\begin{tabular}{|l|l|l|}
\hline Nature of Transport & NO of Responses & NO of Responses\% \\
\hline Personal & 07 & $39 \%$ \\
\hline Rickshaw & 11 & $61 \%$ \\
\hline Public & --- & --- \\
\hline
\end{tabular}

As we can see distance between home and school still be a deterrent to female participation in school. Girls $(60 \%)$ said When transportation was not available they walked to school or did not go to school. Mothers $(70 \%)$ told the effect of incompleteness of primary education is the problems of distance between home and school. The issue of the security of daughters is very significant so they don't use public transport (Suzuki) and fare of rickshaw is very expensive ( 6000 per month at least). If such distance is perceived by parents to be manageable but problematical then in general it is more likely that the enrolment of girls will be adversely affected. For obvious reasons distance between home and secondary school is normally greater than for primary. Furthermore the secondary sector is even more likely to be incomplete, making physical access for those girls who qualify particularly difficult, or even impossible. Cost of education can be higher that the schools are farther away. When transportation was not available they walked to school or did not go to school. Its make access to school more difficult than at primary level. Distance to school has more implications for girls than for boys as we have seen above.

TABLE 17 Ratio of Respondents siblings attending school

\begin{tabular}{|l|l|l|}
\hline $\begin{array}{l}\text { Ratio of Respondents siblings attending } \\
\text { school }\end{array}$ & Responses & Responses $\%$ \\
\hline Yes & 26 & $52 \%$ \\
\hline No & 05 & $10 \%$ \\
\hline Dropped & 15 & $30 \%$ \\
\hline Enrolled son not daughters & 03 & $06 \%$ \\
\hline Enrolled daughters not son & 01 & $02 \%$ \\
\hline
\end{tabular}

As can be seen from the table below 8.2 Poor accesses to education is due to poverty among families and communities, the conservatism and illiteracy of parents, low budgetary allocations to the education sector, and an acute shortage of public schools

Although primary education is officially free of charge, in essence it is not free because schools charge different kinds of informal fees (e.g., exam fees, admission fees, readmission fees). The direct costs of schooling such as school uniforms and supplies can be beyond the means of the poor.

TABLE 18 Causes of out of School children (siblings of Respondents)

\begin{tabular}{|l|l|l|}
\hline Causes & No of Respondents & No of Respondents \% \\
\hline Early Marriage & 04 & $20 \%$ \\
\hline Distance of school & 05 & $25 \%$ \\
\hline Customary Practice & 03 & $15 \%$ \\
\hline Household Duties & 03 & $15 \%$ \\
\hline Difficulties in Studies & 02 & $10 \%$ \\
\hline Lack of interest & 03 & $15 \%$ \\
\hline Poor income level & 15 & $75 \%$ \\
\hline
\end{tabular}


Table 19 Scholarship Program of Respondents (Girls)

\begin{tabular}{|l|l|l|}
\hline Did you get scholarship & No of Respondents(Girls) & No of Respondents\% \\
\hline Yes & 09 & $31 \%$ \\
\hline No & 20 & $79 \%$ \\
\hline
\end{tabular}

TABLE 20 Scholarship Program of Respondents (Mothers) children

\begin{tabular}{|l|l|l|}
\hline Did your child get scholarship & No of Respondents(Mothers) & No of Respondents\% \\
\hline Yes & 05 & $20 \%$ \\
\hline No & 20 & $80 \%$ \\
\hline
\end{tabular}

Government involved in addressing the crucial problem of enabling girls, especially in low income areas, to progress to the secondary sector, which often involves the construction of new facilities, as well as providing scholarships to cover fees, uniforms, books and other necessary expenses. The present incentive system does not contribute to bringing out-of-school children into the classroom because the scholarships are directed only $31 \%$ students and 79\% were those already in school but didn't know about scholarship program. As far as secondary education is concerned there is a real need for incentives in the form of scholarships for girls. Mothers said $(80 \%)$ the distribution system should ensure that poor and deserving children will continue to receive scholarships until they complete secondary and higher education because the decisions to award scholarships have very limited scholarship quotas so the impact of scholarship programmes is minimal for retaining children in school and aspirations for higher education.

"I want to come to school very much" - only $11 \%$ of the Respondents (Girls) in the survey disagreed with this statement, $75 \%$ agreed and $14 \%$ were those who said they want to come and have got scholarship with other facilities(books, uniform, free fees) "At what level do you want to get Education?" only $04 \%$ of the Respondents (Girls) in the survey replied to become Matriculate, 11\% don't know and 85\%wants to become graduate and post graduate.

To examine parents' and children's educational expectations, the following questions were respectively used in the data analysis: "Why do you want your daughters to get education?"

Career choices by girls were strongly influenced by parents with more limited experience and fewer role models, operated within a smaller range of choices, doctor (24\%), teacher (34\%), Manager (6.6\%), computer programmer (07\%), others(15\%)and 13\%dont know .

When parents were asked their expectation and perception about their daughter's education, their response shows $75 \%$ of the parents wish their daughters to get high education and government should provide facilities to them $15 \%$ of the parents wish their daughters to get job and financially support family $10 \%$ remained neutral. The girl's own ideas about their future offspring showed that their plans are for provide higher education to them, not only in the elite where this might be expected, but also in poorer onset(girls from Dhobi Mohala, Kumhar Mohala etc.)

TABLE 21 Respondents (Girls) Parents Documents status

\begin{tabular}{|l|l|l|l|}
\hline Levels & N.I.C & Birth Certificate & Nikahnama \\
\hline No of Respondents & 24 & 7 & 21 \\
\hline No of Respondents $\%$ & $80 \%$ & $23.3 \%$ & $70 \%$ \\
\hline
\end{tabular}

Although families are asked to produce parents' citizenships or children's birth certificates at the time of enrollment, documents many families specially women do not possess but as can be seen above table $10.180 \%$ respondents (mothers) have their N.I.C, $70 \%$ have their Nikahnama even $24 \%$ possess their birth certificate all.

\section{SUMMARY}

This study investigates factors affecting girl's education at the secondary level in Sukkur. To one side from financial factor, cultural and social factors are the major barriers for girls to attend secondary and higher education in Sukkur. This study considered various variables to explain why girls are less likely to be enrolled in schools. The results suggest that level of income of parents, education of the parents; customary practices and school distance from home have a significant impact on the schooling decision for girls.

\section{LEVEL OF PARENTS INCOME}

The socio-economic status of parents appears to be the key factor in deciding whether girls go to school or not. It is poverty which is the main obstacle. However, other factors which were point out such as customary practice $(15 \%)$, lack of interest $(15 \%)$, early marriages $(20 \%)$, household duties $(15 \%)$, difficulties in studies $(10 \%)$ and others it is found that they are all linked to lack of adequate financial resources to keep the girls in school. Here $80 \%$ girls were those who never attend school belong to poor families $20 \%$ belong to middle families and none from rich families. Mothers (70\%) belong to poor and middle families said if there is not 
enough money to feed then how parents send their children in to school, then family background also counts a lot. if a child comes from poor family then it results in dropouts and absence. Dropped out respondents (girls)66.6\% belong to poor families while 05 girls dropped out of school in the 5 th grade, 08 in the 9 th grade, one in the $10^{\text {th }}$ grade, and 02 in the 11 th grade

This is the factor related to the costs ( school fees, cost of uniform, books, stationary etc..) of sending girls to school as well as the overall poverty of the family and the income level, It was the most common reason for no enrolment and dropout(75\%).). Recent government policies (Scholar ship program) though have really reduced the direct cost of schooling for the parents.

"I am going to school easily because I am receiving 2500 Rs. Scholarship every month" (Respondent from Gharibabad said). Despite these efforts however, the study has shown that

here are still other direct costs to schooling which are acting as constraints to enrolling

and keeping girls in school (scholarship distribution limitations ). What other strategies are necessary in Sindh in order to have every child in Sindh enrolled and stay in school? This is one of the questions to be addressed in this study.

Therefore poor income level is a principal factor but girls are affected differently by its various indexes. In the same communities where poor income level rules highest $(75 \%)$ there are also individuals who still stick at school. This then demands for a conduct which looks at each of the factors recommended to poor income level separately. Especially, when families are esteem forced the current income will significantly shape the family's ability to invest in children's education. This finding is expected and financial resources are essential to for the families to be able to invest in the children's education, especially when there are no public supports available. The family level of prosperity shows a significantly positive association with the girls' education. ( $70 \%$ enrolled girls belong to rich families and $80 \%$ girls were those who never attend school belong to poor families, $20 \%$ belong to middle families and none from rich)

\section{PARENTS EDUCATION}

Another factor that is very important for the girl's schooling decision is the parental education.

According to result we can say parents' education is an influential factor of their children's educational attainment $(85.8 \%$ enrolled respondent's fathers were those who attend school and $44.7 \%$ fathers were those who enrolled in higher secondary(above inter) classes and $72.1 \%$ fathers were those who enrolled in secondary(above matric) while $92.1 \%$ mothers were those who attend school and $37.7 \%$ mothers enrolled in higher secondary classes $61.8 \%$ mothers enrolled in secondary classes ) that means educated parents are more willing $(100 \%)$ to send their children to schools and Parental education is positively and significantly related to both boys' and girls' education..

\section{SCHOOL DISTANCE}

All the secondary schools are very far away rather primary schools. In this respect, they are indeed serving the purpose of reducing distance to school for the young girls. Poor location of schools disadvantages pupils, girls are particularly affected. . This condition is not ideal for girls education and their negative impact on girls in particular, were noticeable.

\section{CULTURAL FACTOR}

In order to explore these factors, the study examined the underlying forces of such aspects as cultural practices, beliefs and attitudes, religion and power relationships in the household and how all these influence girls' schooling. In examining cultural practices, beliefs and attitudes the study sought to investigate parental and community attitudes towards the education of boys and girls. Findings from separate focus group interviews that were conducted with girls, mothers, and principals shown that generally parents' attitudes towards the education of both boys and girls are very positive while in some communities (Dhobi Mohala, Kumhar Mohala) children were not allowed to get education but young mothers interviews indicated that they realized that both educated boys and girls were not only a source of pride to the community but also good for the development of the community and the country as a whole. Mothers admitted that although in the past boys education was valued more than girls', the trend had changed in recent years. In principle, parents acknowledged that they recognized their moral obligation to provide equal schooling opportunities to their children.

Our results show that, among the significant factors of girls' never attendance are: household level of prosperity, parents' education and customary practices in the community. Whereas the most significant predictor of children's dropout is the school distance from home, not availability of transport, parents income level, in addition to household level of wealth, parents' education, and cost of education per learner in the community. 


\section{Recommendation}

We show that despite the spectacular increase in basic education enrollments in Sindh, yet there are still challenges ahead before Pakistan can achieve universal basic education, particularly for girls. Data on respondents (mothers' reported) reasons for school never attendance and dropout reveals that direct costs of education, low income level, school distance from home, child disinterest in school, customs and traditions, and poor government planning are significant reasons barriers to girls education. Despite much effort during the past years and significant progress in putting girls in school, much remains to be done in achieving universal basic education. It is therefore the responsibility of everybody, the parents, the communities, the government as well as the education system to solve the problem of girls' education. The recommendations presented in this paper are derived from the problem solution backgrounds conducted with mothers and principals in the communities and the following recommendations were made in the light of data analysis, interpretation and results:

- The study recommends that government should make deliberate efforts to enhanced the provision of transport facilities.

- The study also recommends that that the ministry of education must make sure that enhance the scholarship program to every child not even primary education but provide for secondary and higher secondary education. Increase the size of scholarships so that the money is enough to come across educational costs. Establish a school community boards at the local level to identify girls capable for scholarships, distribute the scholarships accordingly and monitor how they are used.

- Poverty has been recognized as another restrictive to girls' education in this study. It is therefore recommended that government and other welfare organizations interested in girls' education should prefer to have provided to financial support that would enable their parents to engage in some form of income generating facility.

- There is need to provide educational facilities to female population. The government may make such policies that establish secondary and higher secondary schools near or short walking distance from their homes for increasing female enrolment in education. There is need to introduce free of corruption and compulsory education from primary education up to higher secondary education.

- The study has identified direct and indirect cost (fees, uniform, books, other learning materials, cocurricular activities) as an important constraint to sending girls to school. Introduce welfare schooling programs to those girls who are not allowed to go to secondary schools and other children who cannot attend formal secondary schools and provide them allowances (scholarships, free textbooks, uniforms and nutrition) for cost of education.

- During study when asked children and mothers, "why they want to get education or to their children, most of them answered in formal and traditional aspect. The study strongly recommends that the ministry of education must make sure that parents and children must correct their perception about the goals of education.

\section{Conclusion:}

In this study, only a few parental and cultural variables were used, although it can be assumed that many other factors affect children's educational attainment. Due to the unavailability of information, limited human resources, and time constraints, many important variables were excluded from the study. For example, mothers' decision power at home and fathers dominant role for girls education may have been important variables. This would have explained how the amount of income spent on children affected their educational attainment. In addition to the household and community factors excluded from the study, there were other explanatory variables that were left out due to the focus of the paper and the availability of the information. These included the quality of school system, the amount of scholarship for each child in the school, and the location of the school. Also, community' attitudes on education and values could play a significant role in children's educational attainment. However, these factors cannot be measured.

The study explores how parental and other socioeconomic factors affect children's educational attainment. The study find that a strong relationship exists between educational attainments and three factors: parent's education, household income, and school distance from home. On the other hand, the relationship between these cultural variables, customary practice, early marriage, religious factors and children's educational attainment did not work out like the socioeconomic literature suggested.

\section{Acknowledgement}

I would like to extend my sincere thanks to those who provided support in the preparation of this report. First, and foremost, I wish to register my particular gratitude to the Almighty God I would also like to thank to my supervisor Dr. Fakhrul Huda Siddiqui, for his support, devotion of his time and enthusiasm to read my work. 
I would like to express my sincere thanks to all members of Women \& Family Commission Sindh specially Chairperson Ms. Atia Nisar, as they helped me to conduct the survey and accomplish this study. I would not forget my all teachers and friends who helped me in providing information by filling the questionnaires. A special note of gratitude goes to my husband and children for his love, support and understanding.

\section{References:}

[1]. Carr, Wilfred \& Stephen Kemmis. (1986). Becoming Critical: Education, Knowledge and Action Research. London: The Falmer Press.

[2]. A Guide to the Literature By Stephen H. Aby and James C. Kuhn IV Nargis Ara \& Dr. Sufiana. K. Malik (2012). Gender Discrimination in Education- A Barrier in Development of Female Education at Higher Secondary Level, In Interdisciplinary Journal Of Contemporary Research 330 , Vol 4, NO 5, P 330-339

[3]. Anderson, M. B. 1988. "Improving Access to Schooling in Third World: a review", Bridge Research Report Series, No.1.

[4]. 1615-1660. Anderson, M. B. 1988. "Improving Access to Schooling in Third World: a review",. Bridge Research Report Series, No.1. Bakis, O., Levent, H.

[5]. Dollar, D. and R. Gatti 1999. "Gender Inequality, Income, and Growth: Are Good Times Good for Women?", Policy Research Report On Gender and Development Working Paper Series, No. 1, Development Research Group/PREMN.

[6]. Glewwe, P., and H. Jacoby. 1994. "Student Achievement and Schooling Choice in Low Income Countries: Evidence from Ghana", Journal of Human Resources, 29(3): 841-864

[7]. King, E. M., and M. A. Hill. 1993. Women's Education in Developing Countries: Barriers, Benefits, and Policies. Baltimore and London: The Johns Hopkins University Press.

[8]. Lloyd, C., and A. Blanc. 1996. "Children's Schooling in Sub-Saharan Africa: The Role of Fathers, Mothers, and Others", Population and Development Review, 22(2): 265-298.

[9]. Moll, P. 2000. "Discrimination Is Declining in South Africa but Inequality Is Not", Studies in Economics and Econometrics, 24(3): 91-108.

[10]. Parish, W., and R. Willis. 1993. "Daughters, Education, and Family Budgets: Taiwan Experiences", Journal of Human Resources, 29(4): 863-898.

[11]. Rankin, B., and I. A. Aytac. 2004. "The Determinants of the Gender Gap in TurkishEducation”, unpublished mimeo, American Sociological Association Meeting.

[12]. Saccone, D. 2008. "Educational Inequality and Educational Poverty: the Chinese case inthe period 1975-2004", University of Torino Working Papers, No. 08/2008.

[13]. Sahn, D., and S. D. Younger. 2007. "Decomposing World Education Inequality", SAGAWorking Paper, No 187.

[14]. Tansel, A. 2002. "Determinants of School Attainment of Boys and Girls in Turkey: individual, household, and community factors", Economics of Education Review, 21:455-470.

[15]. Datt, G., Jolliffe, D., and Sharma, M. (1997). A Profile of Poverty in Egypt. Food Consumption and Nutrition Division of the International Food Policy Research Institute. FCND Discussion Paper No. (49). Washington, D. C. 1998.

[16]. Elkogali, S. and Suliman, E. 2001. Poverty, Human Capital and Gender: A comparative Study of Yemen and Egypt. ERF working paper (forthcoming).

[17]. Filmer, D. 1999. The structure of social disparities in education: Gender and wealth. World Bank, Washington DC.

[18]. Fergany, N., 1994. Survey of access to primary education and acquisition of basic literacy skills in three governorates in Egypt, Almishkat, Cairo, Egypt.

[19]. Egypt Ministry of Education 1993. "Al Taaleem Lilgamea" (Education for All). Meeting of Nine Countries on Education for All. Ministry of Education, Cairo, Egypt.

[20]. Gwatkin, D., et al., 2000. Country Reports on Socio-Economic Differences in health, Nutrition, and Population. The World Bank.

[21]. Ravallion, M. and Quentin, W. 1999. Does Child Labor Displace schooling Schooling? Evidence on Behavioral Responses to an Enrollment Subsidy. World Bank, Washington DC.

[22]. Rachel Croffie Quayson, Alberta. Tutor at Wesley Girls High School.

[23]. Patricia Assoumoni (Primary and JSS teacher at Pedu M/A School).

[24]. Abban, Barbara. Regional Girls Education Officer. Interview by author, Nov. 2003. Cape Coast.

[25]. written the Regional Education office in Cape Coast.

[26]. El Daw A. Suliman \& Safaa E. El-Kogali, WHY ARE THE CHILDREN OUT OF SCHOOL?: Factors Affecting Children's Education in Egypt, A Paper for the ERF 9th annual conference Washington, DC

[27]. Athanasou, J. A. \& Cooksey, R. W. (2001). Judgment of factors influencing interest. An

[28]. Australian Study. Journal of Vocational Education Research, 26(1), 77-96.

[29]. Jacqueline S. E., \& Pamela E. D., (2005). Influences of Parent's Education on Their Children

[30]. Educational Attainments. London Review of Education, 3(3) pp. 191-204 